\title{
Near-to-Surface properties affecting bond strength in concrete repair
}

\author{
Luc Courard $^{\mathrm{a},{ }^{*}}$, Tomasz Piotrowski ${ }^{\mathrm{b}}$, Andrzej Garbacz ${ }^{\mathrm{b}}$ \\ ${ }^{a}$ University of Liège, Faculty of Applied Sciences, ArGEnCO Department, Chemin des \\ Chevreuils, 1, 4000 Liège, Belgium \\ ${ }^{\mathrm{b}}$ Warsaw University of Technology, Faculty of Civil Engineering, Department of Building \\ Materials Engineering, Al. Armii Ludowej 16, PL 00637 Warsaw, Poland
}

\begin{abstract}
One of the main processes for repairing concrete structures is patch repair. Efficiency and durability of a repaired system depends on the bond between concrete substrate and repair material. By increasing the surface roughness, the surface treatment of concrete substrate can promote mechanical interlocking that is one of the basic mechanisms of adhesion. Nevertheless, some problems may arise from "co-lateral" effects of the treatment, especially due to the development of microcracks inside the substrate. In the presented paper, the effect of concrete substrate surface preparation has been characterized by roughness measurement, description of microcracking in the near-to-surface layer and a pull-off cohesion test. After repair, pull-off bond strength has been evaluated. It is concluded that selection of a suitable surface treatment technique should be preceded by the analysis of its aggressiveness in relation to the concrete substrate strength. A procedure for bond strength estimation using multiple regression approach, based on parameters describing surface quality really generated from various roughening techniques, is then proposed.
\end{abstract}

Keywords: Concrete, Surface treatment, Adhesion, Mechanical interlocking, Repair, Roughness, Microcracking, Pull-off test

\section{Introduction}

\footnotetext{
* Corresponding author. Tel.: +32 436693 50; fax: +32 436695 20; e-mail address: Luc.Courard@ @ulg.ac.be (L. Courard)
} 
A good quality bond between an overlay and concrete substrate is an important requirement for assuring efficiency of repair [1]. According to Silfwerbrand (see Figure 1), the creation and the durability of the bond depends on several factors, each acting with different degrees of influence [2] and can be divided into three main groups [3]. From these, Silfwerbrand pointed out five major factors: microcracking, absence of laitance layer, cleanliness before to overlay placement, compaction and curing procedures. The three first parameters are directly related to substrate characteristics, which can be modified by surface treatment. Treatment of concrete substrate is commonly used for cleaning, removing laitance layer and roughening the surface. However, it can induce microcracking if it is not well operated with regard to the quality and the strength of concrete [4-6]. Even if roughening is not considered as the most important factor for interface quality [2], it seems however to influence bond strength.

Fig.1 Factors affecting bond between concrete substrate and repair material

Bond quality is usually characterized by a fracture stress related to the process of breaking the bond between bodies that are already in contact [7]: another approach considers the process through which two bodies are brought together and attached (bonded) to each other: in this case, the kinetics of contact is of prime importance. Creation of the bond can be explained in terms of specific and mechanical adhesion. Specific adhesion can be evaluated by studying the interfacial and surface forces acting at the interface, specifically the conditions for good wettability and spreading [8]. Good wettability contributes to a better fulfilling of the concrete surface profile by the repair material. Mechanical adhesion is coming from interlocking effect induced by roughening concrete surface. Analyses already made $[8,9]$ showed that the roughness of the substrate prior to repair is a common factor influencing both specific and mechanical adhesion. 
According to EN 1504 [10] and RILEM recommendations [11,12], preparation of the concrete substrate is the fundamental operation which is considered for every "principle" related to concrete repair. Damaged and deteriorated concrete and, where necessary, sound concrete should be removed by means of a surface treatment operation $[13,14]$. In selecting the most appropriated surface treatment method, it is possible to take off only specific quality of concrete. Moreover, increasing roughness promotes adhesion due to better mechanical interlocking for high strength concrete substrates [5]. This is confirmed by Santos et al. [6] for concrete-to-concrete systems with two concretes of $50 \mathrm{MPa}$ and $46 \mathrm{MPa}$ compressive strengths, respectively. Many authors (eg. $[2,4,15,16])$ indicate that microcracking may be a problem, especially in weak substrates. That is why EN 1504 [10] stated: "microcracked or delaminated concrete including that caused by the techniques of cleaning, roughening or removal which reduces bond or structural integrity, shall be subsequently removed or remedied".

The fundamental objective of this research project is to estimate the quality of concrete substrate and to evaluate its surface roughness by means of quantitative parameters with regard to adhesion. In the present paper, influence of substrate quality resulting from different surface treatments is particularly analyzed and mathematical relations between surface properties and bond strength are established.

\section{Materials}

Several repair systems have been tested with different concrete substrate qualities. The research program was divided in two stages. In a first step, performed at the University of Liege (Group A), three different types of concrete and four types of surface treatment techniques were used in order to obtain differences in profile development, surface roughness and level of microcracking in the near-to-surface layer [15]: polishing (PL) as a reference smooth surface, dry sandblasting (SB-D), jack hammering $(\mathrm{JH})$ and high pressure waterjetting 
(250 MPa) called “hydrodemolition” (HD). Jack hammering is using here a hammer with a special head used for roughening $(\mathrm{JH})$ : it is called "sccrabling" in ACI Repair Manual [17]. In a second step, performed at the Warsaw University of Technology (Group B), concretes with other compressive strengths and less aggressive techniques were best suited to obtain similar profiles and low-level microcracking. Brushing (BR) with a metallic brush, wet sandblasting (SB-W), scarification (SC) and waterjetting with a low pressure of $12 \mathrm{MPa}(\mathrm{LC})$ were used for concrete surface preparation. Mix proportion and compressive strengths $\left(f_{\mathrm{ck}}\right)$ are presented in Table 1 for each concrete and concrete substrate samples after surface treatment are listed

in Table 2. After substrate quality evaluation, concrete slabs were covered by commercial polymer cement repair mortar (PCC) with specific technical characteristics presented in Table 3.

Table 1 Mix proportions and compressive strength of concrete substrates for Groups A and B

Table 2 List of concrete substrate samples after surface treatment

Table 3 Technical characteristics of polymer-cement repair mortars (PCC) as given by the producer

\section{Substrate surface characterization - test methods and results}

\subsection{Roughness}

Many approaches are valuable to quantify surface roughness [6,16,18]. EN 1504 [10] recommends visual observation, the use of a profile meter or sand test for this purpose. An original visual surface quantification is also proposed by ICRI (ACI) [17]: nine reference rough plates are placed near to actual concrete and compared to the surface roughness $[19,20]$. 
These Concrete Surface Profile (CSP) chips allow a classification from 1 to 9 but are really limited to surface preparation suited for coatings: maximum proposed roughness is smooth and do not represent more aggressive surface preparation like water jetting or jack hammering. One of the most common method for roughness measurement is the volumetric sand patch technique presented in Figure 2. It is also recommended by EN 1766 [21] for measurement of surface macrotexture depth of concrete substrate prior to repair: a constant volume of specific sand is sprayed on the concrete surface and the diameter of the "circle" is measured. Surface Rough Index (SRI) is calculated using the following equation (1):

$$
\mathrm{SRI}=\mathrm{V} / \mathrm{d}^{2} \cdot 1272[\mathrm{~mm}]
$$

where: $\mathrm{d}$ - mean sand patch diameter $[\mathrm{mm}], \mathrm{V}$ - volume of sand used in the test [ml].

A lower value of SRI indicates a smoother concrete surface.

Fig.2. Sand test for surface roughness evaluation

Profilometry methods commonly used in surface engineering have also been recently implemented for concrete surface characterization. Calculation of statistical and amplitude distribution parameters of the profile allows a quantitative and objective evaluation of the surface geometry [22]. Profile can be obtained by means of profilometers (mechanical and laser) or digitalization of the cross-section image $[6,16]$. A combination of profiles can be also extended onto surfometry, resulting in a 3D image of the real surface [23]. More recently, a new way of surfometry quantification has been developed. Optomorphology, a technique of relief identification is based on the deformation's measurement of a parallel fringes pattern projected on a surface [24] and allows for a digitalization of the surface, as presented in Figure 3. 
Fig.3 Surfometry profiles of C40-PL (a) and C40-HD (b) obtained by optomorphology [23]

Garbacz et al. [11] showed that the surface geometry of the substrates tested is discriminated by similar parameters, whatever the filtration level is. Authors' investigations $[16,23,24]$ show similar relationship for C40-A when comparing results of SRI and mean arithmetic deviation of total profile $(\mathrm{Pa})$ obtained by optomorphology. Relation between Pa vs. SRI is presented in Figure 4. Results obtained for laser profilometry and optomorphology are different in values while the same SRI: this is due to the fact that the filtration of the signal was not applied in case of optomorphology. This was already observed in previous research [23]. However, conclusions remain the same: the higher SRI increases, the higher Pa.

Fig.4 . Relation between Pa obtained by laser profilometry and optomorfology vs. SRI

The results of substrate surface roughness measurement are presented in Table 4. The substrates of Group A can be ranked from polished smooth surface (PL) to very rough hydrodemolished surfaces (HD) and intermediate like dry sandblasted (SB-D) and jack hammered $(\mathrm{JH})$. In Group B, surface treatment techniques had relatively low influence on profile roughness.

Table 4 Results of Surface Roughness Index (SRI), surface tensile strength (fhs) and pull-off bond strength (fh) vs. surface treatment technique

\subsection{Microcracking}

In the case of concrete of relatively low quality, beside the surface roughness, the presence of cracks in the near-to-surface layer is a very important factor that may affect the 
adhesion of repair systems. As the aggressiveness of the surface treatment techniques was low for the samples of Group B, no significant microcracking was observed, even if already observed for scarification [15]. For samples of Group A, microcracking was observed. The density of microcracks $\left(\mathrm{L}_{\mathrm{A}}\right)$ was evaluated on the cross-section of the $80 \mathrm{~mm}$ cores in the near-to-surface layer up to $20 \mathrm{~mm}$ depth. This depth was selected on the base of conclusions made by Bissonnette et al. [15], who obtained for heavy weight $(21 \mathrm{~kg})$ jack hammering + sandblasting maximum depth of microcracking below $20 \mathrm{~mm}$. Based on crack identification and registration, the density of microcracks $\left(\mathrm{L}_{\mathrm{A}}\right)$ was calculated according to the equation (2):

$$
\mathrm{L}_{\mathrm{A}}=1_{\mathrm{A}} / \mathrm{A}\left[\mathrm{mm} / \mathrm{cm}^{2}\right]
$$

where: $1_{\mathrm{A}}=\Sigma 1-$ the sum of microcrack lengths $[\mathrm{mm}]$ and $\mathrm{A}=\mathrm{d}_{0} \cdot 1_{0}-$ the observed area $2 \times 8=$ $16 \mathrm{~cm}^{2}$ (Figure 5). Individual microcrack length is measured under microscope on the registered view of the cross-section using a step method by summation of the lengths of straight segments approximating the crack shape.

Fig.5 Scheme of density of microcracks calculation

Values of $\mathrm{L}_{\mathrm{A}}$ and real images of tested substrates are presented in Table 5. It can be concluded that more aggressive surface treatment technique greatly influences microcracking: a density of microcracks two times higher was observed after jack hammering (JH) and hydrodemolition (HD) than after dry sandblasting (SB-D) and polishing (PL), which means a detrimental effect on adhesion capacity.

Table 5 Results of density of microcracks $\left(\mathrm{L}_{\mathrm{A}}\right)$ vs. surface treatment technique

\subsection{Surface tensile strength}


According to EN 1504 [10], the quality of substrate is defined by surface tensile strength $\left(f_{\text {hs }}\right)$ determined by pull-off test according to EN 1542 [25], commonly used for bond strength evaluation $[25,26]$. Bond strength is measured in the following procedure: after coring up to at least $15 \mathrm{~mm}$ depth in the substrate, a $50 \mathrm{~mm}$ diameter steel dolly is glued on the surface and load is applied at a constant speed. According to EN 1542 [25], pull-off strength is measured and failure mode is registered: $\mathrm{A}$ - in the repair material, $\mathrm{A} / \mathrm{B}-$ at interface and $\mathrm{B}-$ in the concrete substrate (Figure 6). In this research program, in order to be able to this test as a quality of substrate measurement, it was also decided to measure not only tensile strength but also to report failures modes (B1 - superficial, B2 - middle, B3 - deep) according to the pattern presented in Figure 7.

Fig.6 Failure modes on pull-off test scheme for bond strength $\left(f_{h}\right)$ evaluation and examples of type A/B (interface) and B (in the substrate) failure modes

Fig.7 Failure modes on pull-off test scheme for surface tensile strength $\left(f_{\mathrm{hs}}\right)$ evaluation and examples of type B1 (superficial), B2 (middle) and B3 (deep) self defined failure modes

The analysis of the results (Table 4) clearly shows that, on the contrary of Group B, the quality of concrete of the Group A samples has no influence on the surface tensile strength after surface treatment. It can be also observed that for surfaces treated by jack hammering $(\mathrm{JH})$ and scarification (SC), more than $50 \%$ of failures appeared in the superficial zone (type B1, Figure 6). This kind of observation was also made by authors [15] and Bonaldo et al. [27] who also used jack hammering and it is undoubtly due to microcracking in the near to surface layer of concrete substrate, as already mentioned.

\section{Bond quality results and discussion}

After 28 days curing, pull-off tests were performed for the evaluation of bond strength $\left(f_{h}\right)$ between concrete substrate and repair layer. Failure modes, according to pattern presented 
in Figure 6, were registered. The results of pull-off bond strength $\left(f_{h}\right)$ are presented in Table 4. Surface preparation effect on samples of Group A can be divided in two groups with regards to EN 1504 [10] and technical properties given by the producer:

- $\quad$ bond strengths after hydrodemolition (HD) and sandblasting (SB-D) are greater than the threshold minimum values for laboratory performances both for structural (2.0 $\mathrm{MPa})$ and non structural repair $(1.5 \mathrm{MPa})$ as well as the value given by the producer for $10 \mathrm{~mm}$ thick layer.

- $\quad$ bond strengths after polishing (PL) and jack hammering (JH) are close to or below these limits.

Looking to the type of failure, an effect of microcracking is clearly visible for jack hammering $(\mathrm{JH})$, where all failures happened in the superficial zone of substrate (type B, Figure 6). For polishing (PL), all failures appeared at the interface (type A/B, Figure 7), probably due to insufficient mechanical interlocking between substrate and repair layer and lower effective surface of contact. Situation is not so clear for dry sandblasting (SB-D) and hydrodemolition (HD) where cohesive B as well as interface A/B failures were observed.

For the Group B samples, the minimum bond strength given by the producer for $10 \mathrm{~mm}$ thick layer is 1,0 MPa. Only the results on substrates $\mathrm{C} 25 \mathrm{~B}$ - for all surface treatments, and $\mathrm{C} 35 \mathrm{~B}-$ apart from C35-BR, are above this level. Moreover, for C50-LC and C50-BR, a total delamination was observed. In comparison with Group A samples, bond strength is much lower, probably due to insufficient development of surface profile.

Generally, a failure mode type B is desirable as it means that the bond between the substrate and repair material is so good that it surpasses the strength of the origin material. However, it is important to analyze the failure mode together with the value of bond strength: e.g. in Group B samples, when quite aggressive surface treatments like scarification (SC) was applied on the weak concrete (C25), the proper failure mode - type B (Figure 7) was observed 
but the value of pull-off bond strength (1.55 MPa) was smaller than in other cases for this Group (LC - 2.20 MPa, BR - 1.60 MPa, SB-W - 2.46 MPa). The same situation is observed for Group A when comparing jack-hammering ( $\mathrm{JH})$ both for $\mathrm{C} 30$ and $\mathrm{C} 40$. It confirms the influence of microcracking on weakening the superficial zone of the substrate.

The relations between surface profile characteristics ( $\left.f_{c k}, S R I, L_{A}, f_{h s}\right)$ and bond strength $\left(f_{h}\right)$ were analyzed by means of a multiple regression on the base of the following parameters:

B regression coefficient: (B coefficient) represent the independent contributions of each independent variable to the prediction of the dependent variable.

$\beta \quad$ standardized regression coefficient: ( $\beta$ coefficient) allows to compare the relative contribution of each independent variable in the prediction of the dependent variable.

$\mathrm{R} \quad$ correlation coefficient

$\mathrm{p}$ statistical significance: the p-level represents the probability of error that is involved in accepting the observed result as valid, that is, as "representative of the population". In many areas of research, the p-level of 0.05 is considered as a "acceptable border-line" error level.

SEE standard error of estimation: describe the accuracy of estimation

SD standard deviation

The results of multiple regression approach are presented in Table 8 . When all the parameters are introduced into a regression model, the accuracy of estimation described by SEE is 0.50 $\mathrm{MPa}$. Although the correlation coefficient $(\mathrm{R})$ is quite large $(0.71)$, the statistical significance is not so high $(\mathrm{p} \leq 0.25)$. Typically, in many areas of sciences, results that yield $\mathrm{p} \geq 0.05$ are considered as "borderline statistically significant" and $\mathrm{p} \leq 0.05$ as "statistically significant". This means that the prediction of bond strength (fh) of the first model has a high probability of error $(25 \%)$. It shows however that only two variables have an important influence in predicting bond strength (fh): fhs and SRI (the biggest $\beta$ coefficient and the smallest statistical significance - p). 
When using only the two most influencing parameters (SRI and $\mathrm{f}_{\mathrm{hs}}$ ), the regression coefficient $\mathrm{R}$ is almost the same (0.70) but the statistical significance value (0.05) shows high reliability of results. Results of the multiple regression approach for Group B are even better $(R=0.82$ and $\mathrm{p}<0.007)$. Another interesting observation comes from a comparison of the influence of SRI and $f_{\text {hs }}$, respectively: while the influence of SRI increase is positive in both cases, the influence of $\mathrm{f}_{\mathrm{hs}}$ is positive for Group A and negative for Group B. It is probably a result of inefficient surface preparation for high strength substrates which require more aggressive technique in order to obtain higher roughening and to develop mechanical adhesion.

Because no bond (total delamination) was observed for two specific subsets - C50-LC and C50-BR -, a multiply regression analysis has been performed with neglecting these results. Although p value increases from 0.007 up to 0.08 , showing a little worse reliability of the model, the other numbers describing correlation are still at satisfactory levels ( $R>0.70$, SEE $=0,67 \mathrm{MPa}$ ) and the importance of fhs is confirmed.

On the base of the results here above, the bond strength evaluation surfaces showing the influence of fhs and SRI on $\mathrm{f}_{\mathrm{h}}$ were plotted (Figure 8).

Table 6 Results of multiple regression approach

Fig.8 Bond strength evaluation surfaces calculated with $\mathrm{f}_{\mathrm{hs}}$ and SRI variables in multiple regression for Group A (a) and Group B (b)

\section{Conclusions}

The impact of concrete substrate surface treatment on bond quality in repair systems has been investigated. Based on the obtained results following conclusions can be drawn: 
- selection of surface treatment technique should be preceded by the analysis of its aggressiveness in relation to the concrete substrate strength, taking into account both the development of the roughness profile and the decrease of surface tensile strength due to microcracks in the near-to-surface layer: for concrete substrates with compressive strength class lower than $\mathrm{C} 30 / 37$, less aggressive treatment is recommended, because it does not generate cracks in the near-to-surface layer. In the case of higher quality concrete substrates, it is better to use more aggressive treatments which significantly increase surface profile and improve the mechanical interlocking;

- $\quad$ surface tensile strength is a very accurate parameter for characterizing the quality of substrate prior to repair and is easier to evaluate than density of microcracks;

- $\quad$ surface roughness is an important parameter influencing the adhesion of repair layer to concrete substrate;

- compressive strength of concrete substrate is not a very important parameter in the evaluation of adhesion in repair systems if surface treatment was properly selected;

- $\quad$ it is possible to quantify the effect of surface treatment on the bond strength evaluation based on the multiple regression approach using surface tensile strength and surface roughness index as explanatory variables. This allows the estimation of the bond strength with an accuracy of about $0.5 \mathrm{MPa}$.

\section{Acknowledgments}

The authors are thankful to Professor L.Czarnecki, Head of the Department of Building Materials Engineering at the Warsaw University of Technology for valuable discussion and remarks. This work has been prepared in the framework of ACI research project Development of Specification and Performance Criteria for Surface Preparation Based on Issues Related to Bond Strength (2006-2009). The research project was also financially supported by the 
Government of Poland (Ministry of Science and High Education) and the Regional

Government of Wallonia, Belgium (Wallonia Brussels International) through Scientific Cooperation Program.

\section{References}

[1] Courard L, Garbacz A. Surfology: what does it mean for polymer concrete composites? Restor Build Monum 2010;16(4/5):291-302.

[2] Silfwerbrand J, Beushausen H. Bonded concrete overlays - bond strength issues. In: Beushausen H, Dehn F, Alexander M.G, editors. Proceedings ICCRRR 2005 International Conference on Concrete Repair, Rehabilitation and Retrofitting, Cape Town, South Africa, Taylor \& Francis Group, London, 2006. p. 19-21.

[3] Silfwerbrand J. Improving concrete bond in repair bridge decks. Concr Int 1990;12(9):61-66.

[4] Garbacz A, Górka M, Courard L. On the effect of concrete surface treatment on adhesion in repair systems. Mag Concr Res 2005;57(1):49-60.

[5] Courard L, Schwall D, Garbacz A, Piotrowski T. Effect of concrete substrate texture on the adhesion properties of PCC repair mortar. In: Aguiar J.B, Jalali S, Camões A, Ferreira R.M, editors. Proceedings ISPIC 2006 International Symposium Polymers in concrete, Guimarães, Oficinas Gráficas de Barbosa \& Xavier, Lda, Braga, Portugal, 2006. p. 99-110.

[6] Santos PMD, Julio ENBS, Silva VD Correlation between concrete-to-concrete bond strength and the roughness of the substrate surface. Constr Build Mater 2007;21(8):1688-1695.

[7] Austin S, Robins P, Pan Y. Tensile bond testing of Concrete repair. Mater Struct 1995;28(5):249-259. 
[8] Courard L. Evaluation of thermodynamic properties of concrete substrates and cement slurries modified by admixtures. Mater Struct 2002;35(3):149-155.

[9] Courard L. Parametric study for the creation of the interface between concrete and repair products. Mater Struct 2000;33(1):65-72.

[10] EN 1504 (2003) Products and systems for the protection and repair of concrete structures - Definitions - Requirements - Quality control and evaluation of conformity, CEN (Brussels).

[11] Courard L, Garbacz A, Wolff L. Evaluation and quality assessment (chapter 4). In: Seidler P. editor. RILEM TC 184 - IFE Industrial floors. RILEM Report 33, RILEM Publications S.A.R.L, 2006. p. 59-89.

[12] Silfwerbrand J, Beushausen H, Courard L. Bond (chapter 4). In: Bissonette B, Courard L, Fowler D.W, Granju J-L, editors. 193-RLS RILEM TC Bonded cement-based material overlays for the repair, the lining or the strengthening of slabs and pavements, Springer, 2011. p. 51-79.

[13] Pretorius J, Kruger D. The influence of surface roughness on the bond strength of concrete repairs. In: Fowler D.W, editor. CD Proceedings ICPIC 01, $\mathrm{X}^{\text {th }}$ International Congress on Polymers in Concrete, Honolulu, Hawaï, 2001: Paper nr 13.

[14] Fukuzawa K, Mitsui M, Numao T. Surface roughness indexes for evaluation of bond strengths between CRFP sheet and concrete. In: Fowler D.W, editor. CD Proceedings ICPIC 01, $X^{\text {th }}$ International Congress on Polymers in Concrete, Honolulu, Hawaï, 2001: Paper nr 12.

[15] Bissonnette B, Courard L, Vaysburd AM, Belair, N. Concrete removal techniques: influence on residual cracking and bond strength. Concr Int 2006;28(12):49-55.

[16] Garbacz A, Courard L, Kostana K. Characterization of concrete surface roughness and its relation to adhesion in repair systems. Mater Charact 2006;56(4-5):281-289. 
[17] ACI Repair Manual, ACI 546R-04: Concrete Repair Guide, American Concrete Institute, 2013.

[18] Courard L. Adhesion of repair systems to concrete: influence of interfacial topography and transport phenomena. Mag Concr Res 2005;57(5):273-282.

[19] Concrete Repair Manual, ACI International, Farmington Hills, MI, USA, 1999.

[20] Perez F, Bissonnette B, Courard L. Combination of mechanical and optical profilometry techniques for concrete surface roughness characterization. Mag Concrete Res 2009;61(6)389-400.

[21] EN 1766 (2000). Products and systems for the protection and repair of concrete structures - Test methods - Reference concretes for testing, CEN (Brussels).

[22] Courard L, Nelis M. Surface analysis of mineral substrates for repair works: roughness evaluation by profilometry and surfometry analysis. Mag Concr Res 2003;55(4):355366.

[23] Perez F, Bissonnette B, Courard L. Combination of mechanical and optical profilometry techniques for concrete surface roughness characterization. Mag Concr Res 2009;61(6):389-400.

[24] Courard L, Schwall D, Piotrowski T. Concrete surface roughness characterization by means of opto-morphology technique. In: Czarnecki L. and Garbacz A., editors. Adhesion in Interfaces of Building Materials: a Multi-scale Approach, Advances in Materials Science and Restoration AMSR No. 2, Aedificatio Publishers, 2007. p. 107115.

[25] EN 1542 (1999) Products and systems for the protection and repair of concrete structures - Test methods - Measurement of bond strength by pull-off, CEN (Brussels). 
[26] Courard L, Bissonnette B. Essai dérivé de l'essai d'adhérence pour la caractérisation de la cohésion superficielle des supports en béton dans les travaux de réparation : analyse des paramètres d'essai. Mater Struct 2004;37(5):342-350 (in French).

[27] Bonaldo E, Barros JAO, Lourenço PB. Bond characterization between concrete substrate and repairing SFRC using pull-off testing. Int J Adhes Adhes 2005;25(6):463474. 


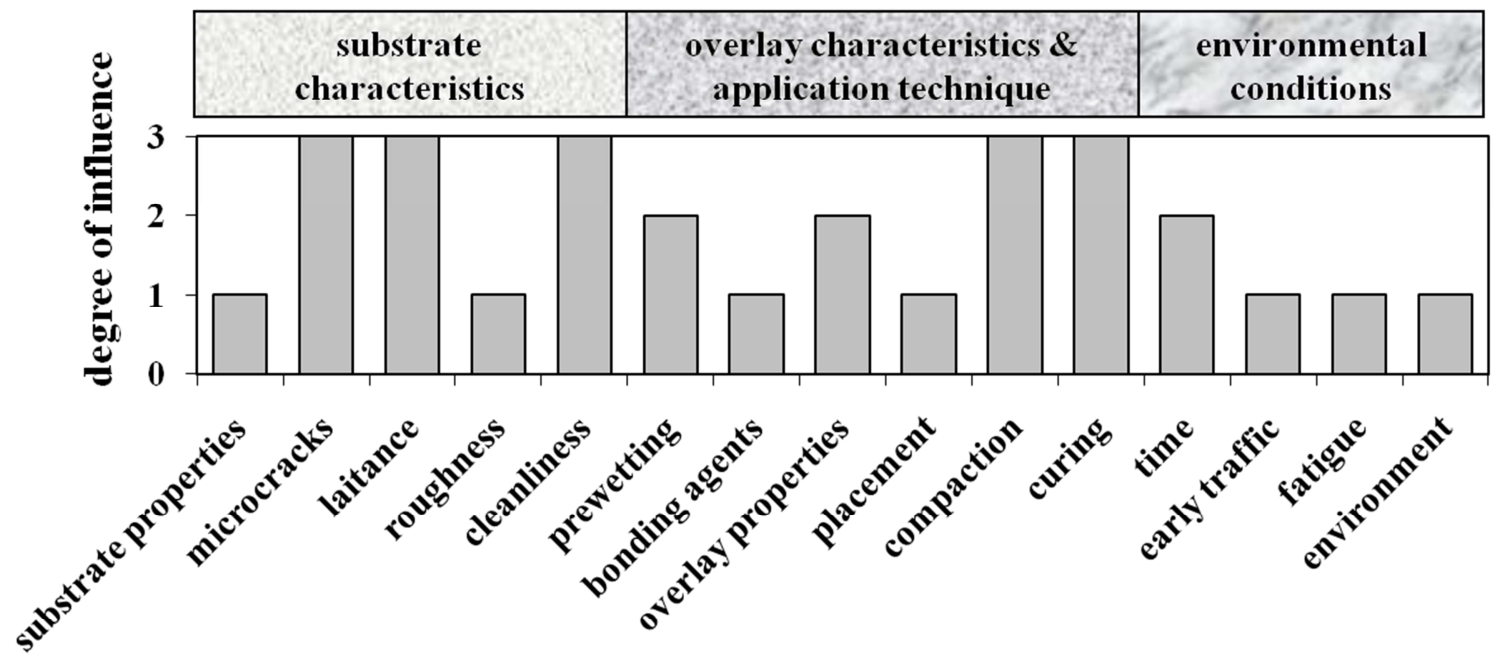

Fig.1 Factors affecting bond between concrete substrate and repair material

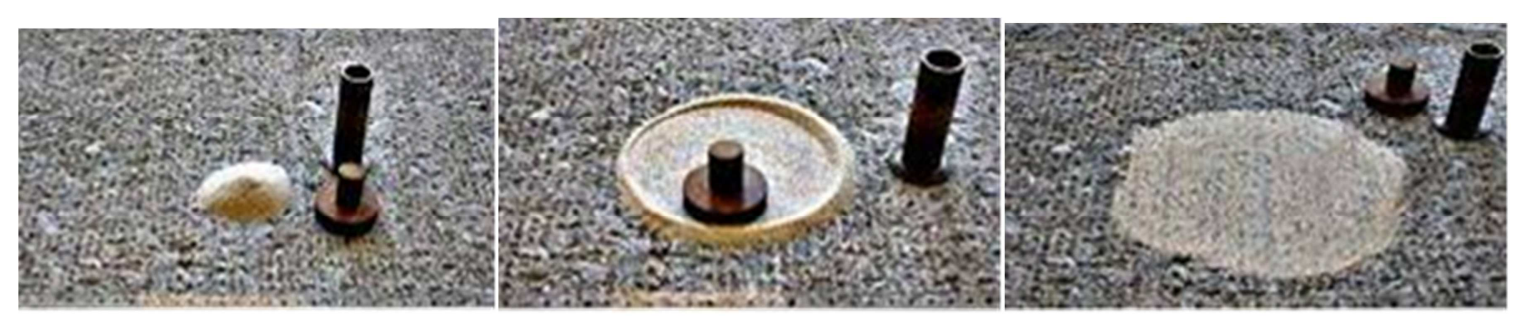

Fig.2. Sand test for surface roughness evaluation 
a)

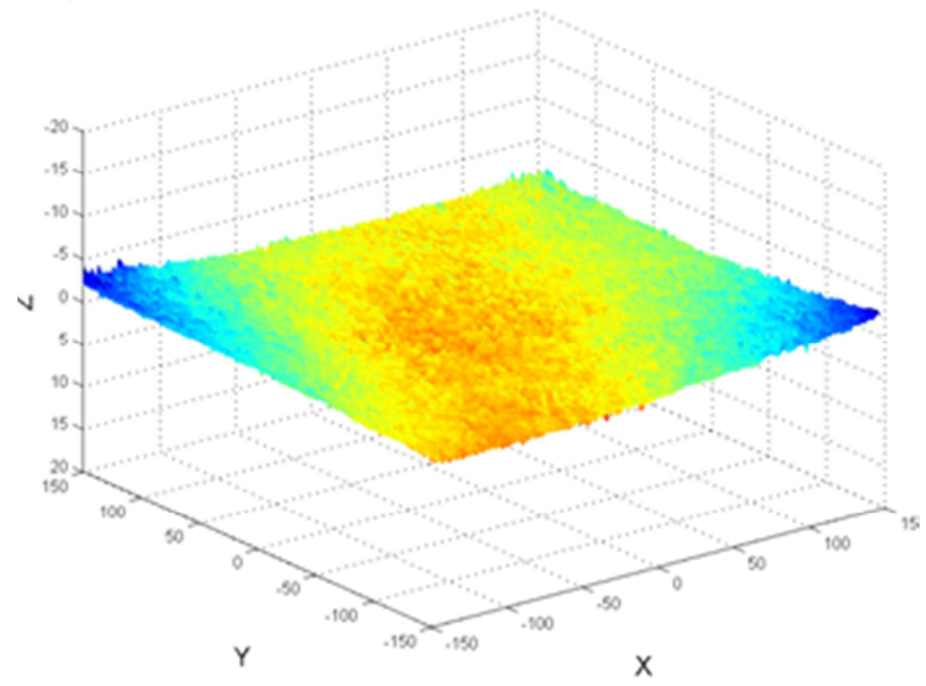

b)

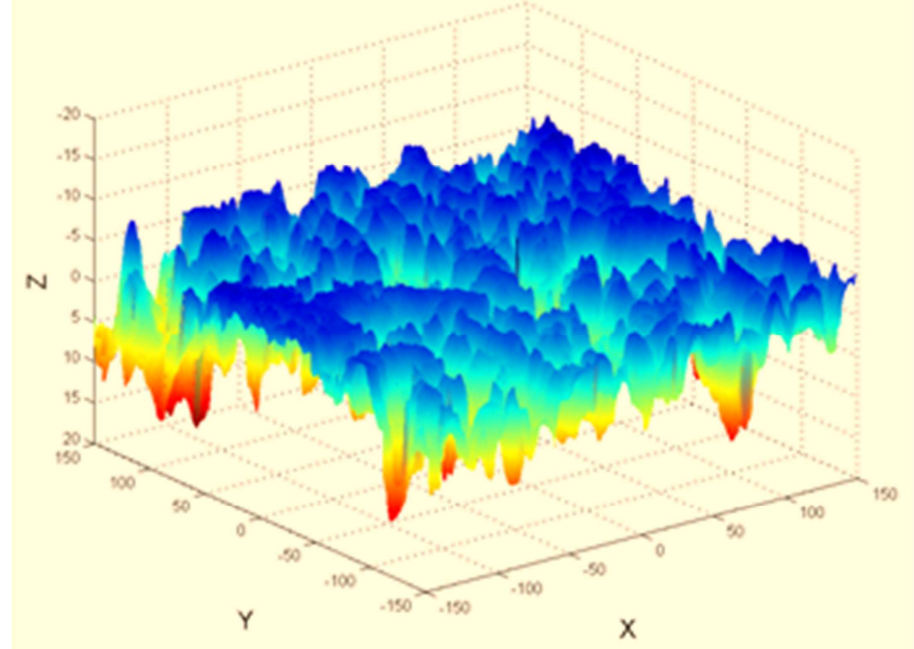

Fig.3 Surfometry profiles [mm] of C40-PL (a) and C40-HD (b) obtained by optomorfology [18]

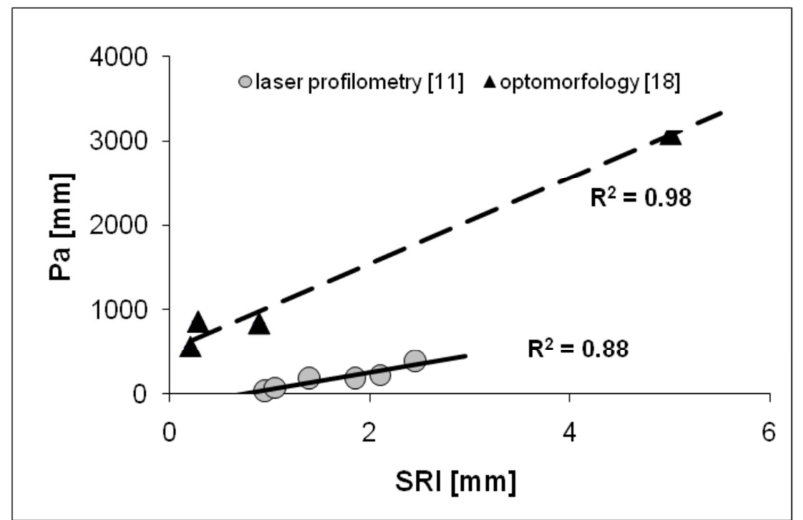

Fig.4 Relation between Pa obtained by laser profilometry and optomorfology vs. SRI 

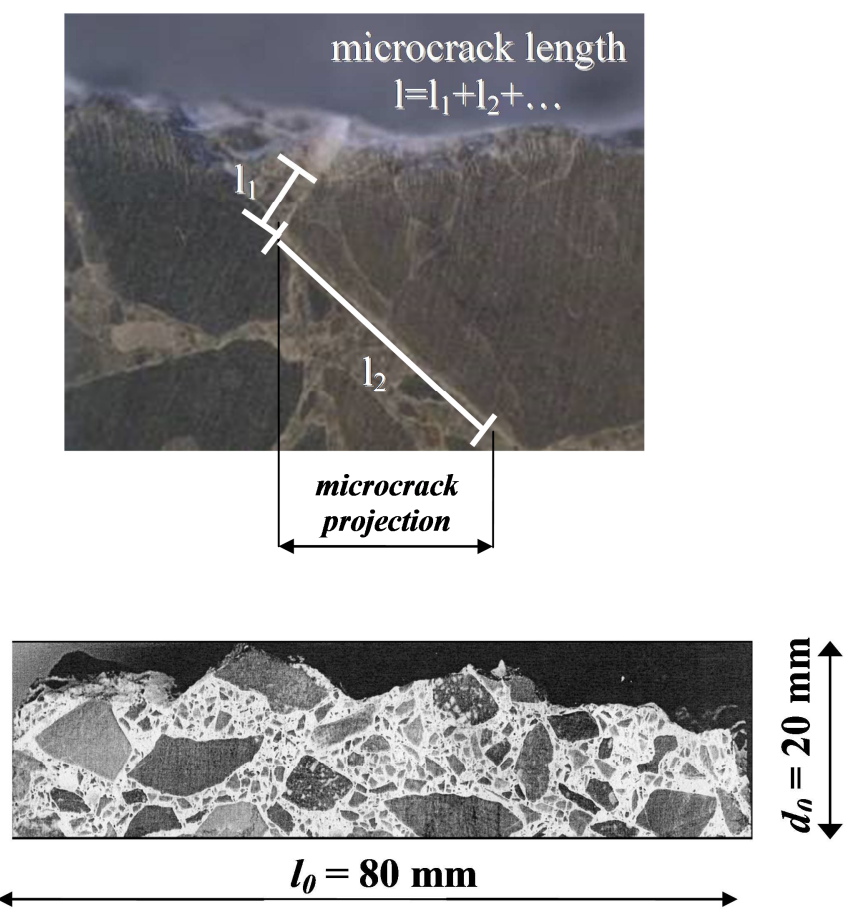

Fig.5 Scheme of density of microcracks calculation

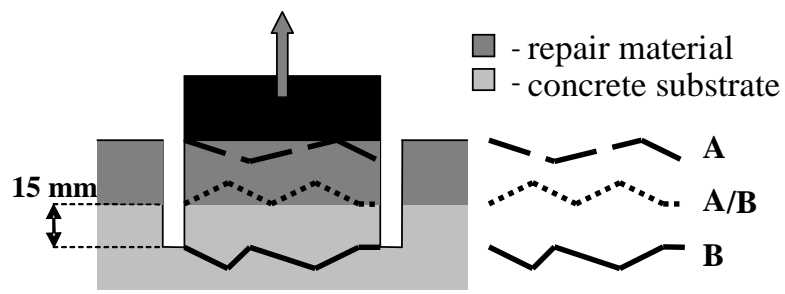

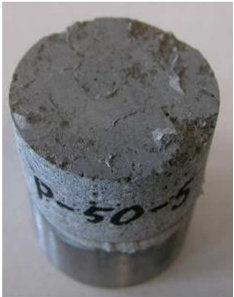

type $\mathrm{A} / \mathrm{B}$

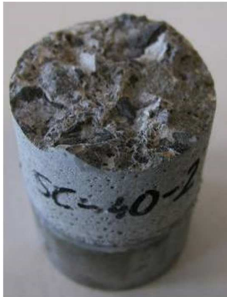

type B

Fig.6 Failure modes on pull-off test scheme for bond strength $\left(f_{h}\right)$ evaluation and examples of type $\mathrm{A} / \mathrm{B}$ and $\mathrm{B}$ failure modes

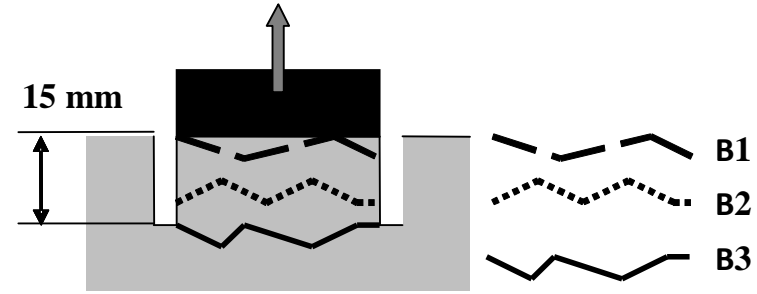

Fig.7 Failure modes on pull-off test scheme for surface tensile strength $\left(f_{\text {hs }}\right)$ evaluation and examples of type B1 (superficial), B2 (middle) and B3 (deep) self defined failure modes 
a)

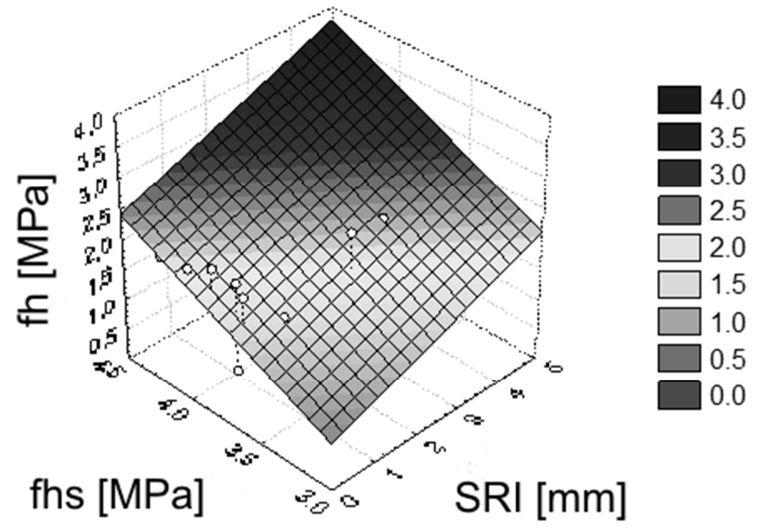

b)

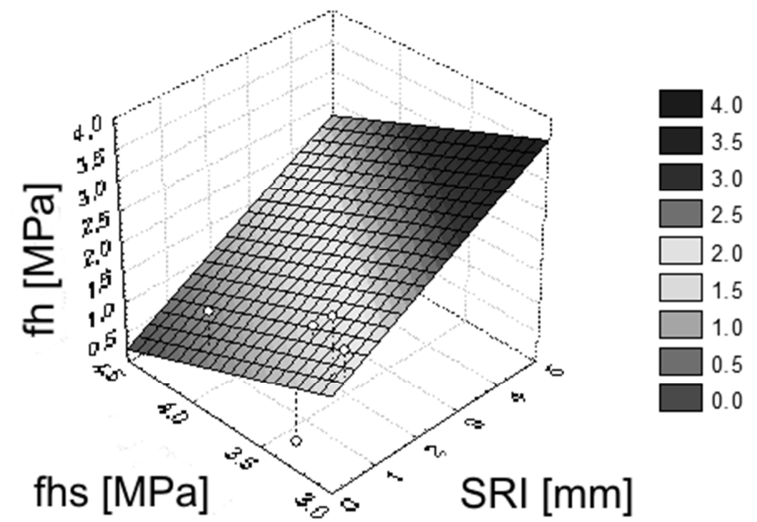

Fig.8 Bond strength evaluation surfaces calculated using $\mathrm{f}_{\text {hs }}$ and SRI variables in multiple regression for Group A (a) and Group B (b). 
Table 1 Mix proportions and compressive strength of concrete substrates for Groups A and B

\begin{tabular}{|c|c|c|c|c|}
\hline $\begin{array}{c}\text { GROUP A } \\
\text { slab } 60 \times 80 \times 10 \mathrm{~cm}\end{array}$ & & $\begin{array}{c}\text { C30A } \\
(\mathrm{C} 30 / 37)\end{array}$ & $\begin{array}{c}\text { C40A } \\
(\mathrm{C} 40 / 50)\end{array}$ & $\begin{array}{c}\text { C45A } \\
(\mathrm{C} 45 / 55)\end{array}$ \\
\hline CEM I 52,5 N & {$\left[\mathrm{kg} / \mathrm{m}^{3}\right]$} & 275 & 325 & 375 \\
\hline River sand $(0 / 2)$ & {$\left[\mathrm{kg} / \mathrm{m}^{3}\right]$} & 765 & 729 & 676 \\
\hline Crushed limestone (2/8) & {$\left[\mathrm{kg} / \mathrm{m}^{3}\right]$} & 255 & 230 & 206 \\
\hline Crushed limestone (8/14) & {$\left[\mathrm{kg} / \mathrm{m}^{3}\right]$} & 569 & 576 & 601 \\
\hline Crushed limestone $(14 / 20)$ & {$\left[\mathrm{kg} / \mathrm{m}^{3}\right]$} & 390 & 401 & 412 \\
\hline Water & {$\left[\mathrm{kg} / \mathrm{m}^{3}\right]$} & 197 & 192 & 188 \\
\hline $\mathrm{W} / \mathrm{C}$ ratio & & 0,72 & 0,59 & 0,50 \\
\hline $\mathrm{f}_{\mathrm{ck}, \mathrm{cyl}, 28 \text { days }}$ & {$[\mathrm{MPa}]$} & 34,96 & 41,34 & 48,77 \\
\hline $\begin{array}{c}\text { GROUP B } \\
\text { slab } 50 \times 50 \times 7 \mathrm{~cm} \\
\end{array}$ & & $\begin{array}{c}\mathrm{C} 25 \mathrm{~B} \\
(\mathrm{C} 25 / 30) \\
\end{array}$ & $\begin{array}{c}\text { C35B } \\
(\mathrm{C} 35 / 45)\end{array}$ & $\begin{array}{c}\mathrm{C} 50 \mathrm{~B} \\
(\mathrm{C} 50 / 60) \\
\end{array}$ \\
\hline$\overline{\text { CEM I 32,5 R }}$ & {$\left[\mathrm{kg} / \mathrm{m}^{3}\right]$} & 350 & 407 & 488 \\
\hline River sand $(0 / 2)$ & {$\left[\mathrm{kg} / \mathrm{m}^{3}\right]$} & 610 & 611 & 604 \\
\hline Gravel 2/8 & {$\left[\mathrm{kg} / \mathrm{m}^{3}\right]$} & 666 & 667 & 658 \\
\hline Gravel 8/16 & {$\left[\mathrm{kg} / \mathrm{m}^{3}\right]$} & 574 & 575 & 567 \\
\hline Water & {$\left[\mathrm{kg} / \mathrm{m}^{3}\right]$} & 189 & 170 & 152 \\
\hline Superplasticizer & {$\left[\mathrm{kg} / \mathrm{m}^{3}\right]$} & - & 1,63 & 7.32 \\
\hline W/C ratio & & 0,54 & 0,42 & 0,31 \\
\hline$f_{\text {ck, cube, } 28 \text { days }}$ & {$[\mathrm{MPa}]$} & 31,47 & 45,67 & 62,10 \\
\hline
\end{tabular}

Table 2 List of concrete substrate samples after surface treatment

\begin{tabular}{ccccc}
\hline $\begin{array}{c}\text { Concrete } \\
\text { substrate A }\end{array}$ & Polishing & $\begin{array}{c}\text { Dry } \\
\text { Sandblasting }\end{array}$ & $\begin{array}{c}\text { Jack } \\
\text { Hammering }\end{array}$ & $\begin{array}{c}\text { Hydrodemolition } \\
\mathbf{2 5 0} \text { MPa }\end{array}$ \\
\hline$C 30 A$ & C30-PL & C30-SB-D & C30-JH & C30-HD \\
$C 40 A$ & C40-PL & C40-SB-D & C40-JH & C40-HD \\
$C 45 A$ & C45-PL & C45-SB-D & C45-JH & C45-HD \\
& & & & Waterjetting \\
Concrete & & Wet & Scarification & MPa \\
substrate B & Brushing & Sandblasting & C25-SC & C25-LC \\
$C 25 B$ & C25-BR & C25-SB-W & C35-SC & C35-LC \\
$C 35 B$ & C35-BR & C35-SB-W & C50-SC & C50-LC \\
$C 50 B$ & C50-BR & C50-SB-W & C50-S & \\
\hline
\end{tabular}


Table 3 Technical characteristics of polymer-cement (PCC) repair mortars (as given by the producer)

\begin{tabular}{|c|c|c|c|c|}
\hline & & & PCC (A) & PCC (B) \\
\hline 1 & Appearance of product & & \multicolumn{2}{|c|}{$\begin{array}{c}\text { Homogeneous loose powder, a uniform color without lumps is } \\
\text { observed after sieving and foreign inclusion }\end{array}$} \\
\hline 2 & $\begin{array}{l}\text { Appearance after mixing with } \\
\text { water }\end{array}$ & & \multicolumn{2}{|c|}{$\begin{array}{l}\text { Uniform mixture of appearance for typical cement mortar, } \\
\text { without lumps and pollutants, not susceptible for segregation }\end{array}$} \\
\hline 3 & Bulk density in loose state & {$\left[\mathrm{kg} / \mathrm{m}^{3}\right]$} & 1450 & 1350 \\
\hline 4 & Grain size $D_{\max }$ & {$[\mathrm{mm}]$} & 2,00 & 0,25 \\
\hline \multirow[t]{3}{*}{5} & Setting time: & & & \\
\hline & - beginning & [min] & $450 \mathrm{~min}$ & $20 \mathrm{~min}$ \\
\hline & - end & [min] & $540 \mathrm{~min}$ & $120 \mathrm{~min}$ \\
\hline \multirow[t]{2}{*}{6} & Bond strength: & & & \\
\hline & - layer of $10 \mathrm{~mm}$ thickness & [MPa] & $\geq 2,0$ & $\geq 1,0$ \\
\hline \multirow[t]{3}{*}{7} & Flexural strength: & & & \\
\hline & - 7 days & [MPa] & $\geq 5,0$ & $\geq 6,0$ \\
\hline & - 28 days & [MPa] & $\geq 8,0$ & $\geq 12,0$ \\
\hline \multirow[t]{3}{*}{8} & Compressive strength: & & & \\
\hline & -7 days & [MPa] & $\geq 50,0$ & $\geq 20,0$ \\
\hline & -28 days & [MPa] & $\geq 60,0$ & $\geq 30,0$ \\
\hline
\end{tabular}

Table 4 Results of Surface Roughness Index (SRI), surface tensile strength $\left(f_{h s}\right)$ and pull-off bond strength $\left(\mathrm{f}_{\mathrm{h}}\right)$ vs. surface treatment technique

\begin{tabular}{|c|c|c|c|c|c|c|c|c|c|c|c|}
\hline \multirow[t]{2}{*}{ Sample } & \multirow{2}{*}{$\begin{array}{l}\text { SRI } \\
{[\mathrm{mm}]}\end{array}$} & \multicolumn{2}{|c|}{$\begin{array}{l}\text { Surface tensile } \\
\text { strength }\left(f_{\mathrm{hs}}\right)\end{array}$} & \multicolumn{3}{|c|}{$\begin{array}{l}\text { Self defined } \\
\text { failure modes }\end{array}$} & \multicolumn{2}{|c|}{$\begin{array}{l}\text { Pull-off bond } \\
\text { strength }\left(f_{h}\right)\end{array}$} & \multicolumn{3}{|c|}{ Failure modes } \\
\hline & & $\begin{array}{l}\text { Mean } \\
{[\mathrm{MPa}]}\end{array}$ & $\begin{array}{l}\mathrm{COV} \\
{[\%]}\end{array}$ & $\begin{array}{l}\mathrm{A} 1 \\
{[\%]}\end{array}$ & $\begin{array}{l}\mathrm{A} 2 \\
{[\%]}\end{array}$ & $\begin{array}{l}\mathrm{A} 3 \\
{[\%]}\end{array}$ & $\begin{array}{l}\text { Mean } \\
{[\mathrm{MPa}]}\end{array}$ & $\begin{array}{l}\mathrm{COV} \\
{[\%]}\end{array}$ & $\begin{array}{c}\text { A } \\
{[} \\
\% \\
]\end{array}$ & $\begin{array}{l}\mathrm{A} / \mathrm{B} \\
{[\%]}\end{array}$ & $\begin{array}{c}\mathrm{B} \\
{[\%]}\end{array}$ \\
\hline \multicolumn{12}{|c|}{ GROUP A } \\
\hline C30-PL & 0.25 & 4.29 & 8.5 & 0 & 0 & 100 & 1.91 & 29.7 & 0 & 100 & 0 \\
\hline C40-PL & 0.20 & 4.07 & 15.0 & 0 & 40 & 60 & 2.04 & 24.7 & 0 & 100 & 0 \\
\hline C45-PL & 0.14 & 3.71 & 7.8 & 0 & 0 & 100 & 0.86 & 29.0 & 0 & 100 & 0 \\
\hline C30-SB-D & 0.29 & 3.70 & 7.1 & 0 & 0 & 100 & 2.04 & 5.3 & 0 & 80 & 20 \\
\hline C40-SB-D & 0.28 & 3.93 & 19.4 & 0 & 0 & 100 & 2.19 & 15.5 & 0 & 100 & 0 \\
\hline C45-SB-D & 0.31 & 3.76 & 15.0 & 0 & 0 & 100 & 2.16 & 25.2 & 20 & 40 & 40 \\
\hline C30-JH & 0.89 & 3.39 & 20.0 & 60 & 0 & 40 & 1.02 & 48.9 & 0 & 0 & 100 \\
\hline C40-JH & 0.89 & 3.51 & 17.2 & 60 & 0 & 40 & 1.42 & 22.7 & 0 & 0 & 100 \\
\hline C45-JH & 0.80 & 3.58 & 10.8 & 100 & 0 & 0 & 1.66 & 13.1 & 0 & 0 & 100 \\
\hline C30-HD & 2.22 & 3.53 & 11.1 & 40 & 0 & 60 & 2.51 & 16.7 & 0 & 20 & 80 \\
\hline C40-HD & 5.00 & 3.54 & 10.6 & 20 & 20 & 60 & 2.54 & 30.4 & 40 & 20 & 40 \\
\hline C45-HD & 3.20 & 3.59 & 14.0 & 20 & 0 & 80 & 2.30 & 22.3 & 0 & 100 & 0 \\
\hline \multicolumn{12}{|c|}{ GROUP B } \\
\hline $\mathrm{C} 25-\mathrm{LC}$ & 0.37 & 3.02 & 18.1 & 33 & 0 & 67 & 2.20 & 9.3 & 25 & 25 & 50 \\
\hline C35-LC & 0.39 & 3.99 & 2.1 & 0 & 33 & 67 & 1.42 & 40.4 & 0 & 100 & 0 \\
\hline C50-LC & 0.16 & 4.98 & 9.1 & 0 & 0 & 100 & 0.00 & - & 0 & $100 *$ & 0 \\
\hline C25-BR & 0.39 & 3.10 & 12.1 & 67 & 0 & 33 & 1.60 & 25.3 & 0 & 100 & 0 \\
\hline C35-BR & 0.39 & 3.37 & 3.6 & 17 & 50 & 33 & 0.13 & - & 0 & 100 & 0 \\
\hline
\end{tabular}




\begin{tabular}{|c|c|c|c|c|c|c|c|c|c|c|c|}
\hline C50-BR & 0.41 & 4.71 & 3.5 & 28 & 28 & 44 & 0.00 & - & 0 & $100 *$ & 0 \\
\hline C25-SB-W & 0.50 & 3.15 & 21.3 & 50 & 17 & 33 & 2.46 & 43.1 & 25 & 0 & 75 \\
\hline C35-SB-W & 0.61 & 2.66 & 7.7 & 66 & 17 & 17 & 2.08 & 25.9 & 0 & 50 & 50 \\
\hline C50-SB-W & 0.41 & 4.48 & 7.2 & 100 & 0 & 0 & 0.14 & - & 0 & 100 & 0 \\
\hline C25-SC & 0.66 & 2.95 & 16.2 & 100 & 0 & 0 & 1.55 & 41.5 & 0 & 0 & 100 \\
\hline C35-SC & 0.88 & 3.39 & 11.2 & 83 & 0 & 17 & 1.81 & 29.0 & 50 & 0 & 50 \\
\hline C50-SC & 0.50 & 4.09 & 6.5 & 67 & 17 & 17 & 0.56 & 26.6 & 0 & 100 & 0 \\
\hline
\end{tabular}

Table 5 Results of density of microcracks $\left(\mathrm{L}_{\mathrm{A}}\right)$ vs. surface treatment technique

\begin{tabular}{|c|c|c|}
\hline $\begin{array}{c}\text { Image of cross-section } \\
\text { of C40 sample }\end{array}$ & Sample & $\begin{array}{c}\mathrm{L}_{\mathrm{A}} \\
{\left[\mathrm{mm} / \mathrm{cm}^{2}\right]}\end{array}$ \\
\hline ives & $\begin{array}{l}\text { C30-PL } \\
\text { C40-PL } \\
\text { C45-PL }\end{array}$ & $\begin{array}{l}1.52 \\
3.23 \\
1.55 \\
\end{array}$ \\
\hline & $\begin{array}{l}\text { C30-SB-D } \\
\text { C40-SB-D } \\
\text { C45-SB-D }\end{array}$ & $\begin{array}{l}2.09 \\
3.45 \\
1.96 \\
\end{array}$ \\
\hline & $\begin{array}{l}\mathrm{C} 30-\mathrm{JH} \\
\mathrm{C} 40-\mathrm{JH} \\
\mathrm{C} 45-\mathrm{JH} \\
\end{array}$ & $\begin{array}{l}4.34 \\
3.89 \\
5.19 \\
\end{array}$ \\
\hline$H^{2}+4 \mathrm{~s}=$ & $\begin{array}{l}\text { C30-HD } \\
\text { C40-HD } \\
\text { C45-HD }\end{array}$ & $\begin{array}{l}3.96 \\
4.91 \\
4.05\end{array}$ \\
\hline
\end{tabular}


Table 6 Results of multiple regression approach

\begin{tabular}{|c|c|c|c|c|c|}
\hline variables & $\beta$ & $\mathrm{SD} \beta$ & $\mathrm{B}$ & SD B & $\mathrm{p}$ \\
\hline \multicolumn{6}{|c|}{ GROUP A, R = 0.71; $\mathrm{p}<0.25 ; \mathrm{SEE}=0.50 \mathrm{MPa}$ (4 variables) } \\
\hline SRI & 0.69 & 0.34 & 0.26 & 0.16 & 0.08 \\
\hline $\mathrm{f}_{\mathrm{hs}}$ & 0.63 & 0.35 & 1.35 & 0.76 & 0.12 \\
\hline $\mathrm{L}_{\mathrm{A}}$ & 0.12 & 0.39 & 5.36 & 17.75 & 0.77 \\
\hline $\mathrm{f}_{\mathrm{ck}}$ & -0.08 & 0.27 & -0.01 & 0.03 & 0.78 \\
\hline free term & & & -3.25 & 3.45 & 0.38 \\
\hline \multicolumn{6}{|c|}{ GROUP A, R = 0.70; $\mathrm{p}<0.05 ; \mathrm{SEE}=0.45 \mathrm{MPa}(2$ variables $)$} \\
\hline SRI & 0.74 & 0.27 & 0.27 & 0.10 & 0.02 \\
\hline $\mathrm{f}_{\mathrm{hs}}$ & 0.58 & 0.27 & 1.25 & 0.58 & 0.06 \\
\hline free term & & & -3.07 & 2.21 & 0.20 \\
\hline \multicolumn{6}{|c|}{ GROUP B, $\mathrm{R}=0.82 ; \mathrm{p}<0.007 ; \mathrm{SEE}=0.60 \mathrm{MPa}(2$ variables $)$} \\
\hline SRI & 0.07 & 0.23 & 0.38 & 1.19 & 0.75 \\
\hline $\mathrm{f}_{\mathrm{hs}}$ & -0.78 & 0.23 & -0.95 & 0.28 & 0.01 \\
\hline free term & & & 4.43 & 1.40 & 0.01 \\
\hline \multicolumn{6}{|c|}{ GROUP B, $\mathrm{R}=0.71 ; \mathrm{p}<0.08 ; \mathrm{SEE}=0.67 \mathrm{MPa}(2$ variables $) *$} \\
\hline SRI & 0.12 & 0.28 & 0.60 & 1.43 & 0.68 \\
\hline $\mathrm{f}_{\mathrm{hs}}$ & -0.67 & 0.28 & -0.97 & 0.39 & 0.04 \\
\hline free term & & & 4.41 & 1.72 & 0.04 \\
\hline
\end{tabular}

